\title{
POLLEN CONCENTRATE PREPARATION FROM HIGHLY ORGANIC HOLOCENE PEAT AND LAKE DEPOSITS FOR AMS DATING ${ }^{1}$
}

\author{
FFIONA RICHARDSON
}

Department of Applied Plant Science, Agricultural Botany Research Division, Faculty of Agriculture and Food Science, Queen's University, Newforge Lane Malone Road, Belfast, BT9 5PX, Northern Ireland

and

VALERIE A. HALL

Institute of Irish Studies, Queen's University, Belfast, BT9 6AW, Northern Ireland

\begin{abstract}
Many of the problems inherent with conventional ${ }^{14} \mathrm{C}$ dating of lake and peat deposits are eliminated by AMS dating of pollen concentrates. Published work describes production of pollen concentrates through expulsion of most of the deposit matrix by repeated deflocculation, selective sieving and final retention of the largest subfossil pollen taxa. Less suited to pollen concentrate production are the highly organic peats and lake muds from the British Isles and Europe. In this study we tested the combined effectiveness of physical, chemical and microbiological degradation and elimination techniques for pollen concentrate production on highly organic peats and a lake mud. We also reviewed methods of enhancing concentrations of smaller sub-fossil pollen grains. Here we present a novel method of assessing AMS dating precision of pollen concentrates by comparing their calibrated dates with a volcanic event of known historical age.
\end{abstract}

\section{INTRODUCTION}

Radiocarbon dating by accelerator mass spectrometry (AMS) minute quantities of subfossil pollen grains eliminates many of the problems inherent with whole deposits and provides an alternative to conventional ${ }^{14} \mathrm{C}$ dating of, for example, Late Pleistocene and Holocene deposits. Some of the components of these deposits may not be contemporary with the pollen (O'Sullivan, Oldfield and Battarbee 1973; Hirons 1988; Peglar, Fritz and Birks 1989; Hall 1990). Brown et al. (1989) and Regnell (1992) have shown how valuable pollen concentrates are for AMS dating.

Using a suite of ${ }^{14} \mathrm{C}$ dated samples from a lowland raised bog peat profile, Pilcher, Hall and McCormac (ms.) have demonstrated the value of high-precision, multisample conventional dating constrained by volcanic ash or micro-tephra from the eruption of the Icelandic volcano Hekla in AD 1104. We suggest that pollen concentrates from a rapidly developing, finely particulate sediment that contains a layer of volcanic ash of known historical age offer a novel method of assessing the precision of AMS dating. Calibrated dates distributed along the ${ }^{14} \mathrm{C}$ calibration curve are assessed against the historical date of the volcanic event. This technique is independent of any comparison with conventionally derived ${ }^{14} \mathrm{C}$ dates (Burleigh, Leese and Tite 1986; Lowe et al. 1988; Regnell 1992). Confirmation of the precision of AMS dates obtained by this method offers an advance on conventional ${ }^{14} \mathrm{C}$ techniques and would be of great value in establishing particularly the dates of Early Holocene volcanic events recorded as tephra layers in sediments of complex origin, for example, the woody fibrous peats commonly found near the bottom of lowland raised bog deposits.

For AMS dating, preparing relatively pure pollen samples requires the removal of the organic fraction of the deposit matrix without using carbon-based chemicals. However, it is mostly organic deposits, often richest in pollen, that present the greatest challenge to preparing pollen concentrates.

'This paper was presented at the AMS Sample Preparation Workshop, 15th International Radiocarbon Conference, 14 August 1994, Glasgow, Scotland 
For standard pretreatment of pollen concentrates for optical microscopy (Faegri and Iversen 1989; Cwynar, Burden and McAndrews 1979; Bowler and Hall 1989), palynologists resort to combinations of destructive chemical and physical procedures, which deflocculate the deposit material and destroy celullose and lignins while leaving the pollen grains intact. None of these processes entirely rids the final sample of non-pollen carbonaceous materials. Microscopic examination reveals that, even after processes that destroy cellulose plant parts, matrix detritus always remains.

Processing organic deposits for AMS dating precludes the use of carbon-based chemicals. Less efficient methods relying on deflocculation of the matrix by solutions of strong alkalis and bleaches (Brown et al. 1989) must be employed. Bowler and Hall (1989) show that these procedures work quite well for relatively finely particulate lake sediments, the more so if they contain sufficient amounts of large pollen grains to comprise a suitably sized sample for AMS dating (Brown et al. 1989). The best combination of procedures for producing pollen concentrates from highly organic deposits has yet to be evaluated.

Preparing pollen concentrates from peats and organic-rich lake sediments from northwest Europe poses two main difficulties:

1. Pollen concentrates based on large pollen grains alone are not generally applicable to many northern European deposits (Bennett 1984; Bradshaw and Brown 1987) as the Late Pleistocene and Holocene pollen flora of this large area is composed principally of species with pollen grains in the size range of $20-50 \mu$.

2. Highly organic peats from lowland raised bogs and upland blanket bogs range in degrees of humification from very poor, in young, lowland raised bog peats, to almost complete at the base of many blanket peat profiles. No single procedure is suitable for all peat deposits.

We intend to develop a rapid and inexpensive method of preparing pollen concentrates from highly organic deposits using readily available materials. This is not because whole deposits are unsuitable for conventional dating, but because we wish to tackle the problem of working with deposit types generally resistant to chemical degradation. To this end, we review the efficiency of published procedures when applied to some of the highly organic types of deposit common throughout the British Isles and northwestern Europe. We report the preliminary results of a microbiological treatment intended to digest fibrous plant parts. In addition, we suggest a procedure for evaluating AMS dates using pollen concentrates from a deposit containing volcanic ash of known historical date.

\section{METHODS AND DISCUSSION}

\section{Site and Sample Selection}

We chose five sample types to represent highly organic deposits. In general, the lowland raised bog peats of the north of Ireland are less decomposed then the upland blanket peats from the same region. They contain almost no inorganic fraction except minute quantities of plant silica, quartz and Icelandic volcanic glass (Pilcher and Hall 1992). All of the test samples were obtained from sites in Northern Ireland. Three lowland raised bog peat samples, variously humified, came from an exposed face at a large lowland raised bog in south County Antrim (Sluggan Bog, Irish Grid Ref. J099921). This is a large area of lowland raised bog peat which has been cut extensively for the provision of horticultural peat products. There is a small remnant of uncut peat from which three sample types were obtained.

Of these, the most poorly decomposed was a recent peat composed of recognizable plant remains, such as leaves and stem fragments of Sphagnum and epidermal and vascular tissue of Eriophorum. 
Two older, more decomposed, peats were somewhat woody, the younger of the two being additionally fibrous.

A highly decomposed upland blanket peat with no recognizable plant structure came from the Mourne Mountains, County Down (Lough Shannagh, Irish Grid Ref. J292258). Extensive areas of blanket peats are present in this area. A coarse detritus lake mud where few plant parts were visible to the naked eye came from Long Lough (Irish Grid Ref. J380556), a small interdrumlin lake, also in County Down. We chose this sediment type so that we could assess the difficulties of working with a largely organic deposit which contained greater amounts of inorganic material than is present in peats.

\section{Pollen Concentrate Preparation}

We report here on the most effective combination of deflocculation, bleaching and sieving techniques from the literature that we used on our samples. We assessed procedures qualitatively, relying on optical comparison of a treated sample with its deflocculated control sample. Comparisons of five replicates per treatments were made by optical microscopic examination.

We made standard pollen pretreatments on all samples to assess the size range of the pollen taxa and the nature of the degraded matrix (Faegri and Iversen 1989). Other samples of each type of deposit were burned (Pilcher and Hall 1992), so that we could assess their inorganic content.

In all cases, examination by optical microscopy showed that the pollen spectrum spanned the size range $20-50 \mu$. Only in the upland blanket peats was there an abundance of Ericaceous pollen grains $>50 \mu$. Knowing the pollen size range is essential when selecting polyester mesh grids for selective sieving. The lowland raised bog peats were almost free of inorganic inclusions such as quartz particles or diatoms. The upland blanket peat contained a small amount of quartz-like material. The lake mud contained fine clay particles and diatoms.

Samples of all deposits were deflocculated in $10 \% \mathrm{KOH}$ solution (Faegri and Iversen 1989). The efficiency of matrix elimination by selective sieving on precision-woven polyester meshes was investigated (Cwynar, Burden and McAndrews 1979; Bowler and Hall 1989) in conjunction with ultrasonic agitation. Another means of deflocculating carbonaceous contaminants, bleaching, was assessed (Brown et al. 1989; Regnell 1992).

We recommend the following combination of procedures:

1. Deflocculate all deposit types in cold $10 \% \mathrm{KOH}$ solution for $12 \mathrm{~h}$.

2. Remove some of the diatoms from the lake mud by treatment with $10 \% \mathrm{KOH}$ solution at $85^{\circ} \mathrm{C}$ for $1 \mathrm{~h}$.

3. Wash samples through precision-woven polyester meshes of the size range 250,120 and $70 \mu$ to remove the larger fraction of the inorganic and organic matrix of all the deposits. A series of washings on meshes of decreasing grid size is more successful for removing the fibrous fraction of the least humified peat than repeated washings through $70 \mu$ polyester mesh alone.

4. A final wash and retention of the sample on $24-\mu$ polyester mesh is a reasonable compromise for all of the deposits in this part of the pollen concentration process. Finer mesh sizes retain more pollen but also more finely particulate matrix fragments. We chose $24-\mu$ mesh even though further elimination of the finer fraction of the matrix caused some pollen loss.

5. Combining washing on $24-\mu$ mesh with agitation in an ultrasonic tank for a maximum of $15 \mathrm{~min}$ greatly improves the concentration of pollen in all samples. This treatment removes virtually all of the finely particulate upland peat matrix, as well as much of the remaining matrix from 
the lake mud. It also benefits the less humified peats by expelling many of the long slender fiber fragments.

6. Milton ${ }^{\mathrm{TM}}$ Sterilising Fluid (Proctor and Gamble Ltd, $2 \% \mathrm{w} / \mathrm{v}$ sodium hypochlorite and $16.5 \%$ w/v sodium chloride solution) is an inexpensive and readily available bleach used to sterilize babies' feeding equipment. Treatment in a half-strength solution of the bleach for 15 min further deflocculates the matrix, which can be removed by washing through $24-\mu$ polyester mesh, with ultrasonic agitation, thus enhancing pollen concentration.

The purest pollen concentrate was prepared from the upland peat. Its matrix was finely particulate and responded well to expulsion by repeated deflocculation and selective sieving. Final samples of this peat were composed of $77 \%$ pollen (Fig.1). The coarser matrices of the lowland peats were much more difficult to remove. No combination of processes was successful in completely removing all plant fibers. A general compromise on bleaching times and sieving has yet to be achieved for poorly humified peat types. Pollen percentages in the final samples of the more poorly humified lowland peats ranged from $16 \%$, in the youngest and most poorly humified peat, to $34 \%$ in the woody and fibrous peat. Final concentration of the pollen content of the lake mud was difficult to estimate. It was clear that most of the organic material had been removed from the final sample but considerable numbers of diatoms remained. Only ca. $25 \%$ of the final sample was composed of pollen. We suggest further improvements to this total below.

In the course of the investigation, we made the following observations:

1. The pollen content of samples was reduced when prepared by ultrasonic treatments lasting longer than $15 \mathrm{~min}$. We suspect that pollen may be destroyed during longer treatments.

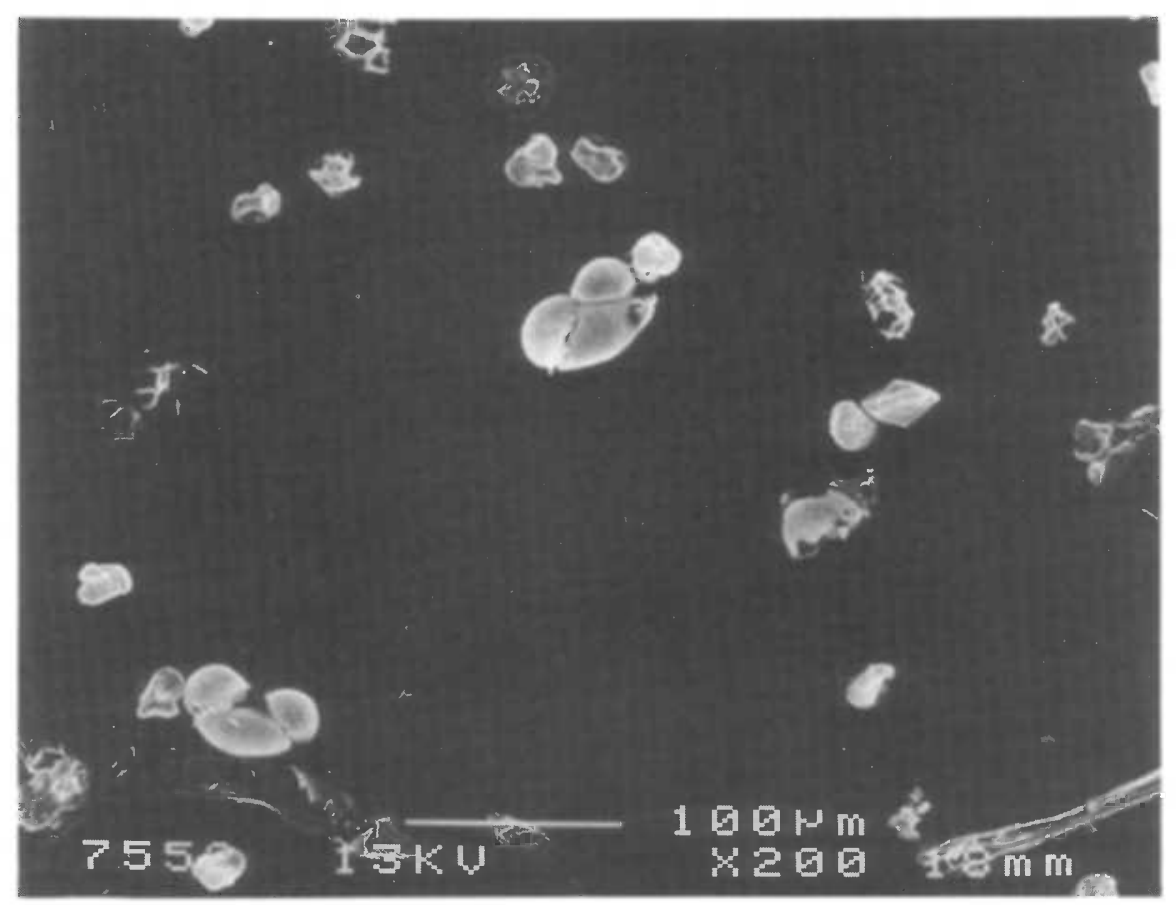

Fig. 1. Pollen concentrate prepared by deflocculation and selective sieving of an upland blanket peat 
2. Matrix deflocculation by bleaching was no more effective after $1 \mathrm{~h}$ than after $15 \mathrm{~min}$. The overbleached material lost of most of its color, making it difficult to assess if more matrix had been expelled after further sieving.

3. Further refinement is needed to prepare almost pure pollen concentrates from fibrous matrices such as poorly humified peats. At this stage, we recommend a compromise between overall sample loss with enrichment of the pollen content versus selective matrix loss using a wider mesh size. We now suggest mesh between 30 and $40 \mu$ and less vigorous sieving. A treatment with hot $\mathrm{HF}$ followed by $\mathrm{HCl}$, a stage in standard pollen pretreatment (Faegri and Iversen 1989), would remove more of the inorganic fraction of the lake mud, in particular, the diatom flora. We stress that these processes must be fine-tuned to the individual requirements of each deposit; compromises depend, in part, on the initial size of the sample and its pollen concentration.

The previous investigations show that chemical treatments alone do little to reduce the size of the coarse fibrous peat fragments. The purity of the pollen concentrate from the upland blanket peat, whose original matrix was fine particulate, shows that the key to good pollen concentrate preparation must include a means of breaking up larger fragments without damaging the pollen. For this reason, we tested a microbiological degradation treatment, which might act similarly to the natural processes of humification.

As most of the matrix material from our subfossil deposits was either cellulose or lignin-based, we chose to test a proprietory microbiological activator, Fertosan ${ }^{\mathrm{TM}}$, used in domestic septic tanks. This product claims to accelerate the breakdown of paper-based products in septic tanks. Fertosan ${ }^{\mathrm{TM}}$ is fungal-based and contains members of the following families and subfamilies: Ascomycetes, Basidiomycetes, Fungi Imperfecti Hypomycetes, Zygomycetes and the bacteria-like Actinomycetes.

We suspended $15 \mathrm{~g}$ (dry weight) samples of whole deposits in culture medium. One set of replicates of each deposit type was also sieved to retain only the $<75 \mu$ fraction of the matrix. After centrifugation, these were also suspended in culture medium. All samples were suspended in $50 \mathrm{ml}$ of aqueous standard chloride-free minimal salts medium to which $1 \mathrm{ml}$ of $0.1 \%$ ammonium nitrate solution was added to provide a nitrogen source. Control replicates contained distilled water only. The $\mathrm{pH}$ of all samples was adjusted to 6.5. Each was innoculated with 20 -ml aliquots of Fertosan ${ }^{\mathrm{TM}}$, prepared according to instructions $\left(80 \mathrm{~g} 1000 \mathrm{ml}^{-1}\right.$ water), and incubated at $30^{\circ} \mathrm{C}$ with occasional stirring.

After six weeks, each sample was washed and sieved through $24-\mu$ polyester mesh. Microscopic examination of the treated peat samples revealed many fibrous fragments, demonstrating that little microbiological digestion had taken place. The treated and untreated digestates looked much the same except for the lake mud samples. Here the deposit was very heavily contaminated with fungal spores the same size as the pollen grains, demonstrating that including fungal digestion in this treatment was counter-productive! Nevertheless, the spores showed considerable microbiological activity and would imply that some species of fungi metabolize the organic component of lake mud as a substrate, which is encouraging.

\section{CONCLUSION}

More work is required to identify a product that will degrade cellulose and related materials in peat without creating more problems than it solves. Other products similar in function to Fertosan ${ }^{\mathrm{TM}}$, but based on bacteria might offer an alternative. An accelerated digestion process, which includes the bacteria and fungi that naturally turn dead plants into peats, should be more promising. Cellulose-decomposing bacteria, such as species of Cellvibrio, Cellulomonas and Pseudomonas, common in the microbiological flora of peat litter, may provide an innoculum. We encourage continued investigation. 
Publications on the preparation of pollen concentrates from whole lake muds have opened the way for more innovative sample preparation techniques for AMS dating. Here we have described our method of preparing samples from some of the most difficult deposits. We expect to continue making improvements.

\section{ACKNOWLEDGMENTS}

We thank Prof. J. R. Pilcher for his comments on the text.

\section{REFERENCES}

Bennett, K. D. 1984 The Postglacial history of Pinus sylvestris in the British Isles. Quaternary Science Reviews 3: 113-155.

Bowler, M. and Hall, V. A. 1989 The use of sieving during standard pollen pre-treatment of samples of fossil deposits to enhance the concentration of large pollen grains. New Phytologist 111: 511-515.

Bradshaw, R. H. W. and Brown, P. 1987 Changing patterns in the Postglacial distribution of Pinus sylvestris in Ireland. Journal of Biogeography 14: 237-248.

Brown, T. A., Nelson, D. E., Mathews, R. W., Vogel, J. S. and Southon, J. R. 1989 Radiocarbon dating of pollen by accelerator mass spectrometry. Quaternary Research 32: 205-212.

Burleigh, R., Leese, M. and Tite, M. 1986 An intercomparison of AMS and small gas counter laboratories. In Stuiver, M. and Kra, R. S., eds., Proceedings of the 12th International ${ }^{14} \mathrm{C}$ Conference. Radiocarbon 28 (2A): 571-577.

Cwynar, L. C., Burden, E. and McAndrews, J. H. 1979 An inexpensive method for concentrating pollen and spores from fine grained sediment. Canadian Journal of Earth Sciences 16: 1115-1120.

Faegri, K. and Iversen, J. 1989 Textbook of Pollen Analysis, 4th edition. Chicester, John Wiley \& Sons: 40-48.

Hall, V. A. 1990 Detecting redeposited pollen in an Irish lake deposit. Irish Naturalists' Journal 23 (10): 389428.
Hirons, K. R. 1988 Recruitment of $\mathrm{cpr}^{2}$ pollen from lake sediments; an example from Co Tyrone, Northern Ireland. Review of Palaeobotany and Palynology 54: 4354.

Lowe, J. J., Lowe, S., Fowler, S. J., Hedges, R. E. M. and Austin, T. J. F. 1988 Comparison of accelerator and radiometric radiocarbon results obtained from Late Devensian Lateglacial lake sediments from Llyn Gwernan, North Wales, UK. Boreas 17: 355-369.

O'Sullivan, P. E., Oldfield, F. and Battarbee, R. W. 1973 Preliminary studies of Lough Neagh sediments. 1. Stratigraphy, chronology and pollen analysis. In Birks, H. J. B. and West, R. G., eds., Quaternary Plant Ecology. London, Blackwell Scientific Publications: 267-278.

Peglar, S. M., Fritz, S. C. and Birks, H. J. B. 1989 Vegetation and land-use history at Diss, Norfolk, U.K. Journal of Ecology 77: 203-222.

Pilcher, J. R. and Hall, V. A. 1992 Towards a tephrochronology for the Holocene of the north of Ireland. The Holocene 2: 225-259.

Pilcher, J. R., Hall, V. A., and McCormac, F. G. (ms.) Dates of Icelandic eruptions from tephra layers in Irish peats. Submitted to The Holocene.

Regnell, J. 1992 Preparing pollen concentrates for AMS dating-a methodological study from a hard-water lake in southern Sweden. Boreas 21: 373-377. 